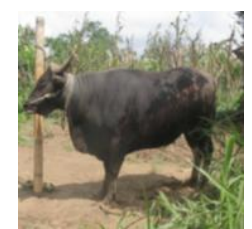

Jurnal

FADET UNUD

\title{
PENGARUH PEMBERIAN MINYAK KALSIUM DALAM RANSUM KOMERSIAL TERHADAP BERAT POTONG DAN LEMAK ABDOMEN BROILER
}

\author{
Andi, I.M., I.M. Suasta, I.G.N.G Bidura
}

PS Sarjana Peternakan, Fakultas Peternakan, Universitas Udayana, Denpasar, Bali email: imadeandi@student.unud.ac.id, Telepon: +6281907494048

\section{ABSTRAK}

Penelitian ini bertujuan untuk mengetahui pengaruh pemberian minyak kalsium dalam ransum komersial terhadap berat potong, lemak bantalan, lemak mesenterium, dan lemak ventrikulus broiler. Penelitian dilaksanakan selama 35 hari di Farm Fakultas Peternakan Universitas Udayana Bukit Jimbaran. Rancangan yang digunakan rancangan acak lengkap (RAL) yang terdiri dari 4 perlakuan dan 6 ulangan. Tiap petak percobaan diisi dengan 5 ekor ayam broiler umur 7 hari dengan berat badan homogen. Keempat perlakuan tersebut adalah ayam yang diberi ransum tanpa minyak kalsium sebagai kontrol (A), dengan pemberian $1 \%$ minyak kalsium dalam ransum komersial (B), pemberian $2 \%$ minyak kalsium dalam ransum komersial (C), dan pemberian 3\% minyak kalsium dalam ransum komersial (D). Variabel yang diamati yaitu berat potong, lemak bantalan, lemak mesenterium, dan lemak ventriculus. Hasil penelitian menunjukan bahwa pemberian minyak kalsium 1-3\%, dalam ransum komersial ternyata berat potong perlakuan $\mathrm{B}$ tidak berbeda nyata $(\mathrm{P}>0,05)$ perlakuan $\mathrm{C}$ dan $\mathrm{D}$ nyata lebih rendah $(\mathrm{P}<0,05)$ dibandingkan perlakuan $\mathrm{A}$. Lemak bantalan ayam yang mendapat perlakuan $\mathrm{B}, \mathrm{C}$, dan $\mathrm{D}$ nyata $(\mathrm{P}<0,05)$ lebih rendah dari perlakuan $\mathrm{A}$ sedangkan lemak mesenterium dan lemak ventriculus tidak berbeda nyata $(\mathrm{P}>0,05)$. Dari hasil penelitian dapat disimpulkan bahwa pemberian minyak 1-3\% dalam ransum komersial dapat menurunkan kandungan lemak abdomen broiler dan pemberian 2-3\% menurunkan berat potong.

Kata Kunci : Broiler, Lemak Bantalan, Minyak kalsium

\section{EFFECTS OF CALCIUM OIL IN COMMERCIAL DIETS ON EIGHT AND ABDOMEN BROILER FAT}

\begin{abstract}
This research aims to determine the effects of calcium oil in commercial diets to broiler pads fat, mesentery fat, and ventricular fat. This research has been conducted for 35 days in Faculty of Animal Husbandry Farm, Located at Bukit Jimbaran, Bali. This Research used completely randomized design (RAL) with 4 treatments and 6 replications. Each plot was filled with 5 chicks 7 day of age with homogeneous body weight. The four treatments were broiler that were diets without calcium oil as a control (A), commercial diets with $1 \%$ of calcium oil (B), commercial diets with $2 \%$ of calcium oil (C), and commercial diets with $3 \%$ of calcium oil (D). The observed variables were weight, pads fat, mesentery fat, and ventricular fat. The results showed that $1-3 \%$ calcium oil in commercial diets, the weight of treatment $\mathrm{B}$ was not significantly different $(\mathrm{P}>0.05)$ and treatment $\mathrm{C}$ and $\mathrm{D}$ were significantly lower $(\mathrm{P}>0.05)$ compared with treatment $\mathrm{A}$. Pads fat on treatment $\mathrm{B}, \mathrm{C}$, and $\mathrm{D}$ were
\end{abstract}


significantly $(\mathrm{P}<0.05)$ lower than treatment A while mesentery fat and ventricular fat were not significantly different $(\mathrm{P}>0.05)$. From the results this research it can be concluded that 1-3\% oil in commercial can reduce broiler abdominal fat.

Keywords: Broiler, Calcium Oil, Padfat

\section{PENDAHULUAN}

Ayam broiler merupakan salah satu ternak unggas yang secara genetik sebagai penghasil daging yang cukup potensial. Kelebihan ayam broiler yaitu pertumbuhannya yang cepat dan efisien dalam memanfaatkan pakan serta harga produk yang relatif terjangkau, sehingga membuat permintaan pasar ayam broiler di Indonesia ayam cukup tinggi (Bidura, 2007). Namun, pertumbuhan ayam broiler yang cepat diikuti oleh pertumbuhan lemak, berat badan ayam broiler yang tinggi tentu berhubungan dengan penimbunan lemak. Kandungan lemak dalam karkas yang tinggi menjadi perhatian khusus bagi konsumen dan produsen ternak. Penimbunan lemak tubuh pada ayam dipengaruhi banyak faktor. Faktor tersebut yaitu strain ayam, jenis kelamin, umur, kualitas dan kuantitas ransum, serta faktor lingkungan seperti kandang, musim, temperatur, serta kelembaban (Wahju, 1997). Karkas yang baik adalah karkas yang mengandung daging dengan kadar lemak rendah dan kandungan protein tinggi.

Tingginya kadar lemak dalam produk pangan asal hewan yang dikonsumsi diketahui menjadi sumber terjadinya obesitas tubuh dan penyakit jantung koroner (Sartika, 2008). Ketakutan terhadap kadar kolesterol yang banyak terdapat dalam bahan pangan asal hewan sangat mempengaruhi tingkat konsumsi produk pangan asal hewan (Sitopoe, 1993). Lemak daging broiler dapat mencapai 20\% dari berat badan (Suthama dan Atmomarsono, 1995) serta mengandung kolesterol sampai $79 \mathrm{mg} / 100 \mathrm{~g}$ berat badan (Supadmo dan Sutardi, 1997). Mengkonsumsi produk dengan kolesterol tinggi berlebihan merupakan salah satu faktor resiko timbulnya penyakit degeneratif, pada makanan tidak melewati ambang standar yaitu $200 \mathrm{mg} / \mathrm{dL}$ dan Low Density Lipoprotein (LDL) lebih rendah dari 100 mg/dL (Oetoro, 2009). Oleh karena itu perlu dilakukan upaya untuk menurunkan kandungan lemak dan kolesterol tubuh pada broiler salah satunya dengan menggunakan minyak kalsium.

Teknologi pemanfaatan limbah minyak sawit merupakan salah satu perlindungan lemak yang akhir-akhir ini banyak dikembangkan. Limbah minyak sawit mengandung asam lemak bebas yang tinggi dan sering digunakan dalam pembuatan sabun dan deterjen sehingga terjadi proses penyabunan yang dapat melarutkan lemak. Lienda et al. (2018) menyatakan minyak kalsium adalah limbah dari penyulingan kelapa sawit menjadi minyak goreng. 
Zulkifli et al. (2003) menyatakan pemberian ransum mengandung minyak sawit yang tinggi mempengaruhi pertumbuhan dan ketahanan ayam broiler terhadap stres panas. Limbah Minyak Sawit mengandung asam lemak jenuh dan tidak jenuh dapat dijadikan sumber energi bahan pakan ternak unggas khususnya ayam untuk mendukung peningkatan produksi daging dan meminimalisir tumbuhnya lemak.

Kendala yang dihadapi apabila digunakan langsung dalam jumlah besar kedalam pakan sulit dilakukan, karena bentuknya yang encer dapat menyebabkan struktur ransum menjadi lengket dan bergumpal. Bentuk seperti itu dapat mempengaruhi teknis pencampuran dan pemberiannya pada ternak. Adapun cara mengatasi hal tersebut adalah menjadikan limbah minyak sawit menjadi tepung kalsium. Pembuatan tepung kalsium yaitu dengan cara limbah minyak sawit direaksikan sedemikian rupa dengan $\mathrm{CaO}$ sehingga menghasilkan tepung kalsium Lienda et al. (2018). Penggunaan tepung limbah minyak sawit tersebut dapat memudahkan untuk pencampuran pakan. Dewi (2003) menyatakan bahwa penggunaan limbah minyak sawit pada ternak dapat membuat pertambahan berat badan, berat karkas dan lemak abdomen lebih baik dibandingkan tanpa menambahan asam lemak sawit. Berdasarkan uraian diatas maka penelitian ini perlu dilakukan untuk mengetahui pengaruh pemberian minyak kalsium dalam ransum komersial terhadap berat potong dan lemak abdomen pada ayam broiler.

\section{MATERI DAN METODE}

\section{Tempat Penelitian}

Penelitian dilaksanakan selama 35 hari dari bulan Maret - April 2019 di Farm Fakultas Peternakan Universitas Udayana dan Laboratorium Ternak Unggas Fakultas Peternakan Universitas Udayana Bukit Jimbaran.

\section{Ayam broiler}

Penelitian menggunakan 120 ekor ayam broiler strain MB 200 platinum produksi PT. Jaffa Comfeed Indonesia Tbk umur satu minggu dengan berat homogen. Broiler diperoleh dengan memelihara broiler dari DOC sampai umur satu minggu tanpa dilakukan pemisahan antara jantan dan betina (unsexing). 


\section{Ransum dan air minum}

Ransum yang digunakan dalam penelitian ini adalah ransum komplit CP 511B produksi PT Charoen Pokphan Indonesia, Tbk. Komposisi bahan penyusun ransum penelitian dapat dilihat pada Tabel 1 .

Tabel 1. Komposisi bahan penyusun ransum penelitian

\begin{tabular}{ccccc}
\hline \multirow{2}{*}{ Bahan ransum $(\%)$} & \multicolumn{4}{c}{ Ransum Perlakuan $^{1}$} \\
\cline { 2 - 5 } & $\mathrm{A}$ & $\mathrm{B}$ & $\mathrm{C}$ & $\mathrm{D}$ \\
\hline Ransum komersial & 100 & 99 & 98 & 97 \\
Minyak kalsium & & 1 & 2 & 3 \\
\hline Total & 100 & 100 & 100 & 100 \\
\hline
\end{tabular}

Keterangan:

1. Ransum kontrol tanpa pemberian minyak kalsium (A), ransum mengandung $1 \%$ minyak kalsium (B), ransum mengandung $2 \%$ minyak kalsium (C), Ransum mengandung 3\% minyak kalsium D.

Minyak kalsium yang digunakan dalam campuran ransum penelitian ini adalah minyak dari limbah kelapa sawit yang direaksikan sedemikian rupa dengan $\mathrm{CaO}$ sehingga menjadi minyak kalsium. Kandungan nutrisi dari minyak kalsium disajikan pada Tabel 2, sedangkan kandungan nutrisi ransum percobaan dapat dilihat pada Tabel 3.

Tabel 2. Kandungan nutrien minyak kalsium

\begin{tabular}{lc}
\hline Zat makanan & Kandungan nutrien \\
\hline Energi Metabolis (Kkal/kg) & 4922 \\
Air (\%) & 7,5 \\
BETN (\%) & 54,24 \\
TDN (\%) & 97,32 \\
Abu (\%) & 18,6 \\
Protein (\%) & 0,8 \\
Lemak kasar (\%) & 31,3 \\
Kalsium (\%) & 3,0
\end{tabular}

Sumber: Lienda et.al (2018) 
Tabel 3. Kandungan nutrien ransum percobaan

\begin{tabular}{lccccc}
\hline \multirow{2}{*}{ Nutrien } & \multicolumn{3}{c}{ Perlakuan $^{1}$} & \multirow{2}{*}{ Standar $^{3}$} \\
\cline { 2 - 5 } & $\mathrm{A}^{2}$ & $\mathrm{~B}$ & $\mathrm{C}$ & $\mathrm{D}$ & \\
\hline Energi Metabolis & 2950 & 2970 & 2989 & 3009 & 2900 \\
(Kkal/kg) & 13 & 12,95 & 12,90 & 12,85 & 14 \\
Kadar Air (\%) & 22 & 21,79 & 21,58 & 21,36 & 19 \\
Protein (\%) & 5 & 5,26 & 5,53 & 5,79 & 7,4 \\
Lemak(\%) & 5 & 4,95 & 4,90 & 4,85 & 6,0 \\
Serat (\%) & 7 & 7,12 & 7,23 & 7,35 & 8,0 \\
Abu (\%) & 0,9 & 0,92 & 0,94 & 0,96 & 1,05 \\
Kalsium (\%) & 0,6 & 0,594 & 0,588 & 0,582 & 0,8 \\
Fosfor (\%) & & & & & \\
\hline Ken
\end{tabular}

Keterangan :

1) Ransum kontrol tanpa pemberian minyak kalsium (A), ransum mengandung $1 \%$ minyak kalsium (B), ransum mengandung $2 \%$ minyak kalsium (C), Ransum mengandung $3 \%$ minyak kalsium D.

2) Brosur pakan PT. Charoen Pokphan Indonesia

3) Berdasarkan Standar Nasional Indonesia (SNI-2006)

Air minum yang diberikan selama penelitian adalam bersumber dari air PDAM (Perusahaan Daerah Air Minum) yang diberikan secara ad libitum.

\section{Kandang dan perlengkapan}

Kandang yang digunakan pada penelitian adalah kandang baterai koloni. Kandang berada didalam bangunan dengan luas $25 \mathrm{~m}$ x $10 \mathrm{~m}$. Luas kandang yang digunakan untuk penelitian berukuran $400 \mathrm{~cm}$ x $60 \mathrm{~cm}$ dengan tinggi $1 \mathrm{~m}$ dari permukaan tanah. Kandang dibagi menjadi 24 petak dengan ukuran per petak perlakuan adalah $100 \mathrm{~cm}$ x $60 \mathrm{~cm}$. Masing masing kandang diisi tempat pakan, tempat air minum dan lampu serta dinding kandang diisi tirai penutup untuk menjaga suhu kandang. Pada kandang juga dilengkapi dengan thermometer untuk mengetahui suhu kandang ayam broiler.

\section{Rancangan penelitian}

Rancangan percobaan yang digunakan adalah Rancangan Acak Lengkap (RAL) dengan 4 perlakuan dan 6 ulangan. Perlakuan A (ayam diberikan ransum kontrol tanpa pemberian minyak kalsium), B (ayam diberikan ransum kontrol dengan pemberian 1\% minyak kalsium), 
C (ayam diberikan ransum kontrol dengan pemberian 2\% minyak kalsium), D (ayam diberikan ransum kontrol dengan pemberian 3\% minyak kalsium).

\section{Pemberian ransum dan air minum}

Ransum diberikan pada ayam secara ad libitum yang artinya tidak terbatas. Pemberian ransum dilakukan dengan menempatkan tempat pakan ayam dalam kandang pada setiap perlakuan. Air minum diberikan secara ad libitum dan diganti agar tetap bersih dan layak diminum oleh ayam.

\section{Pemanenan dan pemotongan}

Pemotongan ayam dilakukan pada saat ayam berumur 35 hari. Untuk pengambilan sampel diambil satu ekor ayam di setiap ulangan yang berat badannya mendekati berat badan rata rata. Sebelum dilakukan pemotongan ayam dipuasakan selama 12 jam tetapi air minum tetep diberikan. Hal ini dilakukan agar pada saat penimbangan mendapatkan berat ayam tanpa makanan. Pemotongan dilakukan menurut USDA (1977), yaitu ayam dipotong pada bagian Vena jugularis yang terletak diantara tulang kepala dengan ruas tulang leher pertama. Selanjutnya darah yang keluar pada saat pemotongan ditampung lalu di timbang beratnya. Setelah ayam dipastikan mati, kemudian dicelupkan kedalam air dingin sebelum dicelupkan ke air panas selama beberapa detik agar pada saat pencabutan bulu kulit ayam tersebut tidak mengelupas. Bagian-bagian tubuh seperti kaki, leher, kepala, paha, dada, sayap, punggung dan organ dalam serta lemak dipisahkan dan dicari beratnya.

\section{Variabel yang diamati}

Variabel yang diamati dalam penelitian ini adalah sebagai berikut

1. Berat potong, diperoleh dengan cara menimbang berat ayam setelah dipuasakan selama 12 jam dan di cari berat rata-ratanya kemudian ayam di potong adalah ayam yang mendekati berat rata-rata.

2. Lemak bantalan : merupakan lemak yang menempel pada perut ayam broiler, dipisahkan dari organ- organ jeroan dan kulit perut lalu ditimbang.

$\%$ Lemak bantalan $=\frac{\text { borat i:mak barkaiar }}{\text { tarat potong }} \times 100 \%$. (Kubena et al., 1974).

3. Lemak mesenterium : merupakan lemak yang terdapat pada usus yang didapat dengan cara memisahkan lemak yang menempel pada usus lalu ditimbang.

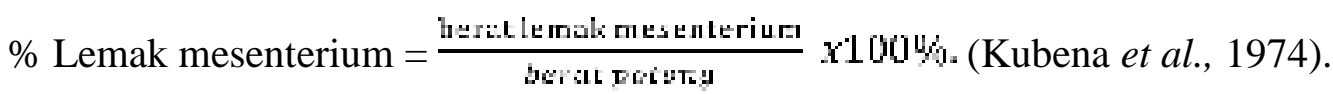

4. Lemak Ventrikulus : adalah lemak yang berada di bagian ventrikulus. Didapat dengan cara memisahkan lemak yang menempel pada bagian ventriculus lalu ditimbang. 
$\%$ Lemak ventrikulus $=\frac{\text { berat le mak ventrikuius }}{\text { barat potong }} \times 100 \%$ (Kubena et al., 1974).

\section{Analisis data}

Data yang diperoleh dianalisis dengan analisis ragam, apabila diantara perlakuan terdapat perbedaan yang nyata $(\mathrm{P}<0,05)$ maka analisis dilanjutkan dengan uji jarak berganda Duncan (Steel and Torrie, 1991)

\section{HASIL DAN PEMBAHASAN}

\section{Berat potong}

Hasil penelitian menunjukan bahwa rataan berat potong pada ayam yang diberikan perlakuan ransum komersial tanpa minyak kalsium sebagai kontrol (A) adalah 2184,83 g/ekor (Tabel 4). Rataan berat potong ayam yang diberi $1 \%$ minyak kalsium pada ransum komersial (B), 2\% minyak kalsium pada ransum komersial (C), 3\% minyak kalsium pada ransum komersial (D) masing-masing berat potongnya sebesar 3,66\%, 7,76\%, dan 6,73\% lebih rendah daripada kontrol (A).

Tabel 4. Pemberian minyak kalsium dalam ransum komersial terhadap berat potong dan lemak abdomen broiler.

\begin{tabular}{llllll}
\hline \multirow{2}{*}{ Variabel } & \multicolumn{4}{c}{ Perlakuan $^{\mathrm{l}}$} & SEM $^{3)}$ \\
\cline { 2 - 5 } & $\mathrm{A}$ & $\mathrm{B}$ & $\mathrm{C}$ & $\mathrm{D}$ \\
\hline Berat Potong (g/ekor) & $2184,83^{\mathrm{a} 2)}$ & $2104,83^{\mathrm{ab}}$ & $2015,17^{\mathrm{b}}$ & $2037,67^{\mathrm{b}}$ & 39,43 \\
Lemak Bantalan (\%) & $1,28^{\mathrm{a}}$ & $1,08^{\mathrm{b}}$ & $1,09^{\mathrm{b}}$ & $1,05^{\mathrm{b}}$ & 0,05 \\
Lemak Mecenterium (\%) & $0,54^{\mathrm{a}}$ & $0,53^{\mathrm{a}}$ & $0,51^{\mathrm{a}}$ & $0,53^{\mathrm{a}}$ & 0,04 \\
Lemak Ventriculus (\%) & $1,18^{\mathrm{a}}$ & $1,08^{\mathrm{a}}$ & $1,10^{\mathrm{a}}$ & $1,00^{\mathrm{a}}$ & 0,06 \\
\hline
\end{tabular}

Keterangan :

1) Ayam yang diberi ransum tanpa pemberian minyak kalsium sebagai kontrol (A), ayam yang diberi ransum mengandung $1 \%$ minyak kalsium (B), ayam yang diberi ransum mengandung $2 \%$ minyak kalsium (C), dan ayam yang diberi ransum mengandung $3 \%$ minyak kalsium (D).

2) Nilai dengan huruf yang berbeda pada baris yang sama menunjukan berbeda nyata $(\mathrm{P}<0,05)$

3) Standard Error Of The Treatment Means

Rata-rata berat potong ayam broiler pada penelitian ini berkisar antara 2015,172184,83 g/ekor (Tabel 4). Berat potong ayam yang mendapat perlakuan C dan D adalah $7,76 \%$ dan $6,73 \%$ berbeda nyata $(\mathrm{P}<0,05)$ dari perlakuan $\mathrm{A}$ hal ini disebabkan karena minyak kalsium mempunyai energi yang tinggi sehingga berdampak terhadap konsumsi pakan. Hal 
ini sesuai dengan pernyataan Moritz et al. (2002) bahwa salah satu yang mempengaruhi besar kecilnya pertambahan berat badan ayam pedaging adalah konsumsi pakan dan terpenuhinya kebutuhan zat makanan akan tetapi ayam yang mendapat perlakuan $C$ dan $D$ tidak nyata 4,6\% dan 3,2\% dari perlakuan $\mathrm{B}$ hal ini disebabkan karena minyak kalsium mengandung asam lemak bebas yang tinggi dan apabila diberikan berlebihan pada ayam broiler maka pertambahan berat badan ayam akan menurun. Pemberian minyak kalsium akan dapat meningkatkan kandungan energi dalam ransum hal ini disebabkan karena kandungan ME minyak kalsium tinggi yaitu sebesar 4.922 (Tabel 3). Peningkatan ME ransum juga akan berdampak terhadap penurunan konsumsi ransum. Bidura (2007) ayam mengunsumsi ransum untuk memenuhi kebutuhan energi, apabila energi terpenuhi ayam akan berhenti makan hal ini sejalan dengan hasil penelitian ini. Penambahan minyak kalsium dalam ransum komersial meningkatkan kandungan energi termetabolis ransum sehingga konsumsi ransum menurun. Penurunan konsumsi ransum akan diikuti penurunan zat makanan yang berdampak pada penurunan berat potong. Untuk lebih rinci penurunan berat potong broiler dapat dilihat pada Gambar 1.

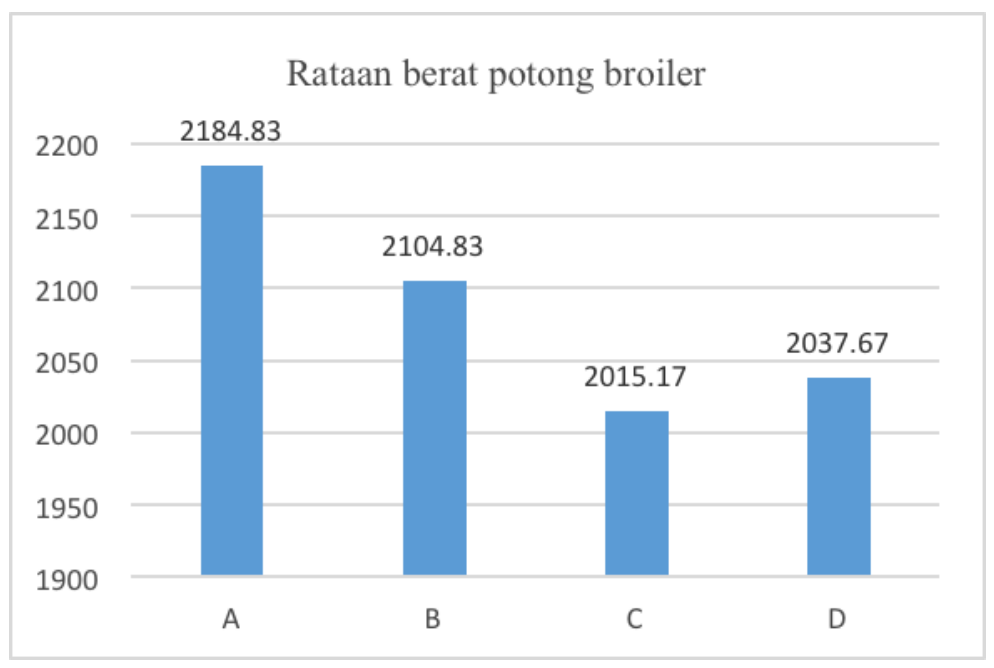

Gambar 1. Grafik rataan berat potong broiler.

\section{Persentase lemak bantalan}

Persentase lemak bantalan broiler tanpa diberikan minyak kalsium (A) adalah 1,28\% dari berat potong (Tabel 4). Rataan berat lemak bantalan broiler pada perlakuan B, C, dan D berbeda nyata $(\mathrm{P}<0,05)$ lebih rendah masing masing 15,62\%, 14,84\%, dan 17,97\% daripada kontrol A. Persentase lemak bantalan yang diberikan perlakuan B masing masing $0,92 \%$ dan $2,78 \%$ dari perlakuan $\mathrm{C}$ dan $\mathrm{D}$ secara statistik tidak berbeda nyata $(\mathrm{P}>0,05)$ sedangkan pada perlakuan D adalah 3,67\% lebih rendah daripada perlakuan $\mathrm{C}$ dan secara statistik tidak 
berbeda nyata $(\mathrm{P}>0,05)$. Perlakuan $\mathrm{D}$ memiliki berat lemak bantalan paling rendah daripada perlakuan A, B, dan C. Dari hasil penelitian pemberian 3\% minyak kalsium dalam ransum komersial (D) menunjukan hasil terbaik yaitu 1,05. Berat lemak bantalan pada perlakuan B, $\mathrm{C}$, dan $\mathrm{D}$ secara statistik berbeda nyata $(\mathrm{P}<0,05)$ dibandingkan dengan perlakuan $\mathrm{A}$.

Penurunan lemak bantalan disebabkan karena minyak kalsium mengandung asam lemak bebas yang tinggi dan sering digunakan dalam pembuatan sabun dan deterjen. Sehingga terjadi proses penyabunan yang dapat melarutkan lemak. Proses penyabunan juga mengakibatkan penurunan enzim lipase yang berfungsi untuk memecah lemak. Penurunan terhadap lemak bantalan juga dikarenakan minyak kalsium mengandung $\beta$-karotein yang dapat merangsang dinding kantong empedu dengan menetralkan kondisi asam dari saluran usus sehingga pembentukan lemak berkurang hal ini sesuai dengan pernyataan Lienda et al (2018) melaporkan bahwa minyak kalsium yang bersumber dari minyak sawit mengandung $\beta$ karotin yang tinggi. Santoso (2009) juga menyatakan bahwa $\beta$-karotein merupakan senyawa aktif penurun lemak pada ternak. Seperti yang dilaporkan oleh Dewi (2003) pemberian limbah minyak sawit dalam ransum nyata dapat menurunkan kadar lemak pada ayam broiler. Menurut Anggorodi (1994), menyatakan bahwa penimbunan lemak dapat terjadi karena kelebihan energi setelah digunakan untuk memenuhi kebutuhan pokok dan untuk produksi dan penimbunan lemak ini dipengaruhi oleh bangsa, sistem kandang, umur, dan jenis kelamin. Tarigan, Sjofan, dan Djunaidi (2013), menyatakan bahwa penimbunan lemak dipengaruhi oleh faktor genetik, jenis kelamin, pertumbuhan, ransum, umur pemotongan dan strain.

Penurunan kadar lemak bantalan juga diduga karena adanya pengaruh $\mathrm{Ca}$ dalam metabolisme lemak. Menurut penelitian Mentari et al. (2014) bahwa terdapat interaksi antara lemak dan kalsium karena metabolisme lemak dapat dipengaruhi oleh keberadaan $\mathrm{Ca}$. Tingginya kandungan $\mathrm{Ca}$ dalam ransum akan menyebabkan metabolisme lemak semakin meningkat yang diakibatkan karena proses penyabunan. Ditambahkan oleh Nisa (2010) bahwa mineral $\mathrm{Ca}$ merupakan satu faktor yang mempengaruhi proses penyabunan dan menyebabkan lemak terbuang sehingga deposisi lemak dalam daging menjadi rendah. Menurut Maryuni dan Wibowo (2005) penimbunan lemak dipengaruhi oleh komposisi ransum anatara lain tingkat energi dalam ransum, perbandingan energi protein dan kadar lemak ransum. Mahfudz et al. (2009) menyatakan bahwa lemak abdominal dan lemak karkas memiliki hubungan korelasi positif, yaitu apabila lemak abdominal meningkat maka lemak karkas juga akan meningkat. Meliandasari et al.(2013) deposisi lemak ayam broiler umumnya disimpan dalan bentuk lemak di rongga perut dan dibawah kulit. Hasil penlitian ini 
menunjukan persentase lemak bantalan berskisar antara 1,05-1,28 lebih rendah jika dibandingkan dengan rata- rata lemak normal yang dilaporkan oleh Summers and Leeson (1984), menyatakan bahwa dalam keadaan normal berat lemak abdominal berkisar antara 1,63,5\% dari berat hidup. Persentase lemak abdomen pada penelitian ini disajikan pada Gambar 2.

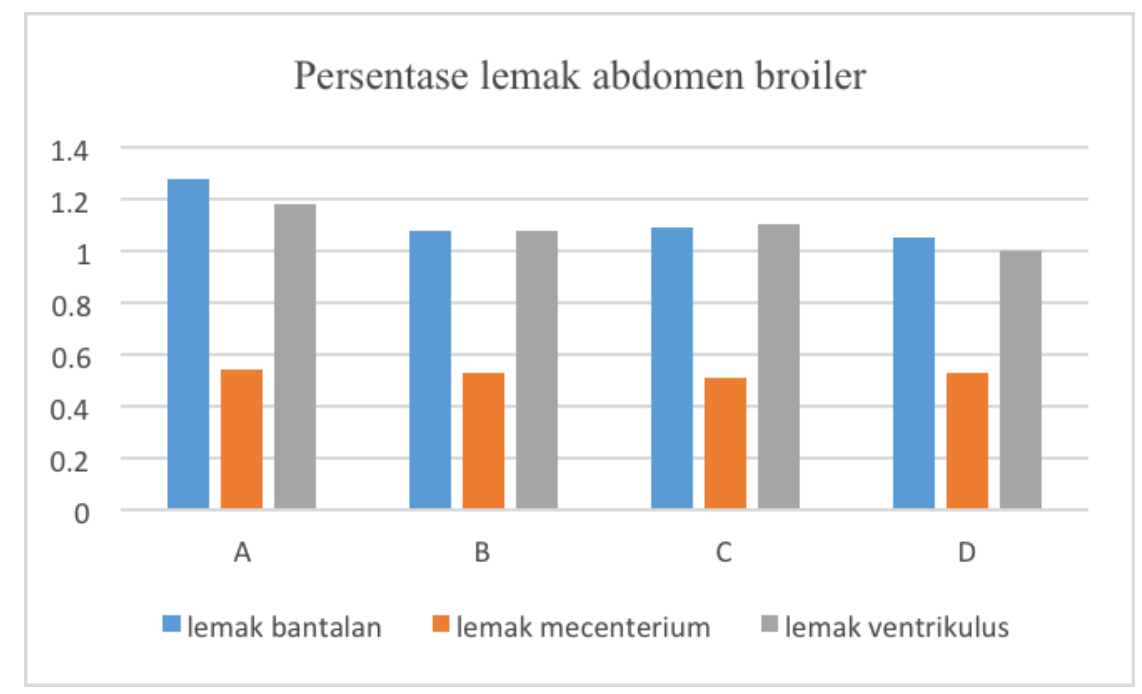

Gambar 2. Persentase lemak abdomen broiler selama pemilharaan

\section{Persentase Lemak Mesenterium}

Persentase lemak mesenterium ayam yang mendapatkan perlakuan kontrol (A) adalah 0,54\% dari berat potong (Tabel 4). Rataan berat lemak mesenterium perlakuan $\mathrm{B}, \mathrm{C}$ dan $\mathrm{D}$ lebih rendah daripada kontrol A masing masing adalah 1,85\%, 5,56\%, dan 1,85\%. Persentase lemak mesenterium yang diberikan perlakuan B dan D adalah sama 3,78\% dari perlakuan C dan secara statistik tidak berbeda nyata $(\mathrm{P}>0,05)$. Pemberian $2 \%$ minyak kalsium dalam ransum komersial (C) menunjukan hasil terbaik yaitu $0,51 \%$ dari berat potong dan secara statistik perlakuan $\mathrm{B}, \mathrm{C}$, dan $\mathrm{D}$ menunjukan perbedaan yang tidak nyata $(\mathrm{P}>0,05)$. Hasil penelitian menunjukkan bahwa pemberian minyak kalsium dalam ransum komersial ternyata tidak berpengaruh nyata terhadap jumlah lemak mesenterium hal ini dikarenakan peranan lemak mesenterium sebagai penggantung usus menyebabkan tidak terjadinya penimbunan lemak. Hal ini sesuai dengan pendapat Santoso (1989), yang menyatakan bahwa tempat terbesar dari penimbunan lemak pada ayam pedaging adalah didalam rongga perut dan tempat ini biasanya digunakan untuk memperkirakan besarnya penimbunan lemak dalam tubuh.

Menrut Bidura (2012) umumnya peningkatkan kandungan energi ransum pada itik hanya akan berpengaruh terhadap persentase lemak bantalan secara genetik ternak unggas 
menyimpan kelebihan energi dalam bentuk lemak umumnya pada lemak subkutan dan lemak abdomen

\section{Persentase Lemak Ventrikulus}

Persentase lemak ventrikulus tanpa diberikan minyak kalsium (A) adalah 1,18\% dari berat potong (Tabel 4). Rataan berat lemak ventrikulus broiler pada perlakuan B, C, dan D lebih rendah masing masing 8,47\%, 6,78\%, dan 15,25\% darpada kontrol A. Persentase lemak ventrikulus yang diberikan perlakuan $\mathrm{B}$ masing masing 1,85\% dan 7,40\% dari perlakuan $\mathrm{C}$ dan $\mathrm{D}$ secara statistik tidak berbeda nyata $(\mathrm{P}>0,05)$ sedangkan pada perlakuan $\mathrm{D}$ adalah 9,09\% lebih rendah daripada perlakuan $C$ dan secara statistik tidak berbeda nyata $(P>0,05)$. Dari hasil penelitian pemberian 3\% minyak kalsium dalam ransum komersial (D) menunjukan hasil terbaik yaitu 1,00. Lemak ventrikulus pada perlakuan B, C, dan D secara statistik menunjukan perbedaan yang tidak nyata $(\mathrm{P}>0,05)$. Hal ini dikarenakan lemak ventriculus hanya menempel pada bagian ventriculus sehingga pada ventriculus tidak terjadi penimbunan lemak dan sesuai dengan pendapat Santoso (1989), yang menyatakan bahwa tempat terbesar dari penimbunan lemak pada ayam pedaging adalah didalam rongga perut dan tempat ini biasanya digunakan untuk memperkirakan besarnya penimbunan lemak dalam tubuh. Dilaorkan oleh Santoso (2002) distribusi lemak pada ayam broiler adalah lemak bantalan, lemak mesenterium dan lemak ventriculus, gabungan ketiga lemak tersebut disebut dengan lemak abdomen.

Menrut Bidura (2012) umumnya peningkatkan kandungan energi ransum pada itik hanya akan berpengaruh terhadap persentase lemak bantalan secara genetik ternak unggas menyimpan kelebihan energi dalam bentuk lemak umumnya pada lemak subkutan dan lemak abdomen dalam hal ini penambahan $\mathrm{Ca}$ dalam minyak kalsium mungkin lebih keliatan peranya dalam pembentukan tulang seperti dilaporkan oleh Bidura dan Gomes (2019) bahwa mineral kalsium sangat erat kaitannya dalam proses pembentukan tulang, kulit telur dan pembentukan darah.

\section{SIMPULAN DAN SARAN}

\section{Simpulan}

Hasil penelitian dapat disimpulkan bahwa pemberian minyak kalsium dalam ransum komersial 2-3\% dapat menurunkan berat potong, sedangkan pemberian minyak kalsium dalam ramsum komersial 1-3\% dapat menurunkan lemak abdomen pada ayam broiler. 


\section{Saran}

Ditinjau dari kualitas karkas yang rendah lemak maka disarankan kepada peternak ayam broiler dan industri pakan ternak bahwa pemberian minyak kalsium 3\% dalam ransum komersial dapat menurunkan lemak abdomen pada ayam broiler.

\section{UCAPAN TERIMA KASIH}

Penulis mengucapkan terima kasih kepada Prof. Dr.dr. A. A. Raka Sudewi, Sp.S (K) selaku Rektor Universitas Udayana dan Dr. Ir. I Nyoman Tirta Ariana, M.S selaku Dekan Fakultas Peternakan Universitas Udayana yang telah memberikan kesempatan dan fasilitas kepada penulis untuk mengikuti dan menyelesaikan pendidikan di Program Studi Sarjana Peternakan, Fakultas Peternakan Universitas Udayana.

\section{DAFTAR PUSTAKA}

Anggorodi, R. 1994. Ilmu Makanan Ternak Umum, Penerbit PT.Gramedia. Jakarta.

Bidura, I.G.N.G. 2007. Aplikasi Produk Bioteknologi Pakan Ternak. UPT Penerbit Universitas Udayana, Denapasar.

Bidura, I.G.N.G. dan Gomez, G. S. 2019 Manajemen Nutrisi Ternak Babi Kebutuhan dan Defisensi zat makanan, UPT Penerbit Universitas Udayana, Denapasar.

Bidura, I.G.N.G. 2012 "Pemanfaatan Kamir Saccharomyces cerevisiae yang Diisolasi dari Ragi Tape untuk Tingkatkan Nilai Nutrisi Dedak Padi dan Penampilan Itik Bali Jantan”. Disertasi Program Pascasarjana, Universitas Udayana. Denpasar.

Dewi, G.A.M.K. 2003. Penggunaan Asam Lemak Sawit Dalam Ransum Untuk Meningkatkan Produksi Ayam Pedaging, Fakultas Peternakan, Universitas Nusa Cendana, Kampus Undana Fenfui.

Dewi, G.A.M.K, P. A. Astawa And I. K. Sumadi. 2011. Effect Of Inclusion Calcium-Palm Fatty Acid (Ca-Pfa) On Growth Performance And Profile Of Body Fatty Acid Of Broiler. J.Indonesian Trop.Anim.Agric. 36(1): 55-60

Kubena, I.F., J.W.Deaton, T.C. Chen and F.N Reece.1974.Factor Influencing The Quality of Abdominal Fat In Broiler. Poultry Science. 53:211.

Lienda A. Handojo, Antonius Indarto, Dian Shofinita, Angina Mritha, Rakhmawati Nabila, and Harry Triharyogi, Maulana G.A. Hakim, and Muhamad R. Saadi. 2018. Calcium soap from palm fatty acid distillate (PFAD) for ruminant feed; quality of calcium. $\mathrm{Ca}(\mathrm{OH}) 2$ as calcium source. MATEC web of conferences 159, 02062 (2018).

Mahfudz, L.D., F. L. Maulana, U. Atmomarsono dan T.A. Sarjana. 2009. Karkas dan lemak abdominal ayam broiler yang diberi ampas bir dalam ransum. seminar Kebangkitan Peternakan. Pemberdayaan Peternakan Berbasis Sumber Daya Lokal untuk Ketahanan Pangan Berkelanjutan. Semarang. 596-605. 
Maryuni, S. S. dan C. H. Wibowo. 2005. Pengaruh kandungan lisin dan energi metabolis dalam ransum yang mengandung ubikayu fermentasi terhadap konsumsi ransum dan lemak ayam broiler. J. Indon.Trop. Anim. Agric. 30(1): 26- 33.

Meliandasari, D., L. D. Mahfuds, dan W. Sarengat. (2013). Pengaruh Penggunaan Tepung Rumput Laut (Gracilaria verrucosa) dalam Ransum terhadap Perlemakan Ayam Broiler Umur 42 Hari. Animal Agriculture Journal, 2(1): 120-127.

Mentari, A.S., L.D. Mahfudz dan N. Suthama. 2014. Massa protein dan lemak daging pada ayam broiler yang diberi tepung Temukunci (Bosenbergia pandurata ROXB.) dalam ransum. Animal Agriculture Journal. 3(2): 211-220 .

Moritz, C, D. Brodercik, KL Dethmers, N.N. FitzSimmon and C. Limpus. 2002 Pupulations Genetick of Southeast Asenan and Western Pasiflc Green Turtles, Chelonia mydas. Final Reportto UNEP/CMS.

Nisa, T. K. 2010. Pengaruh Perbedaan Aras Protein dan Ca ansum terhadap Daya Cerna Lemak dan Warna Hati pada Burung Puyuh Betina Periode. Skripsi. Grower. Fakultas Peternakan Universitas Diponegoro, Semarang.

Oetoro S. 2009. Obat Tradisional Penyakit Kolesterol. http:apotekherbal.com/obat herbal kolesterol darah menurunkan Kadar kolesterol darah. Html. (05 mei 2019).

Santoso, U. 1989. Limbah Bahan Ransum Unggas yang Rasional. PT. Bhratara, Jakarta

Santoso, U. 2002. Aplikasi Teknologi Ekstrak Daun Katuk untuk Meningkatkan Efisiensi Produksi pada Peternakan Ayam pedaging Rakyat. Laporan Pengabdian kepada Masyarakat. (Ipteks). Universitas Bengkulu, Bengkulu, Indonesia.

Santoso, U. 2009. Mengenal Daun Katuk dan Manfaatnya, Jurnal Urip Santoso, http://uripsantoso.wordpress.com. Diakses pada tanggal 4 Januari 2020.

Sartika, Ratu Ayu Dewi. (2008). Pengaruh Asam Lemak Jenuh,Tidak Jenuh dan Asam Lemak Trans Terhadap Kesehatan. Jurnal Kesehatan Masyarakat Nasional, Vol.2, No.4, p.154-160

Sitopoe. 1993. Kolesterol Fobia, Keterkaitanya dengan Penyakit Jantung. Penerbit P.T. Gramedia Pustaka Utama, Jakarta.

SNI- 01- 3930- 2006. Pakan Anak Ayam Ras Pedaging (Broiler Starter). Badan Standarisasi Nasioal (BSN).

Steel, R. G. D. dan J. H. Torrie. 1991. Prinsip dan Prosedur Statistik. Suatu Pendekatan Biometrik. Terjemahan: B. Sumantri. Gramedia, Jakarta.

Summers, J. D. and Leeson, S. (1984). Nutrition Repmts International 40: 29.

Supadmo dan Sutardi, 1997. Pengaruh sumber khitin dan prekursor karnitin serta minyak ikan lemuru terhadap kadar lemak dan kolesterol serta asam lemak omega-3 ayam broiler [disertasi]. Program Pascasarjana, IPB, Bogor.

Suthama, N. dan Atmomarsono, U., 1995. Feeding thyroid hormone related substance its effect on broiler performance and carcass quality. In The 2 th Poultry Science Symposium of the World's Poultry Science Association (WPSA). Proceedings, Indonesian Branch. Semarang. Central Java, Indonesia. 
Tarigan, R,. Sjofan,O,. Dan Djunaidi,I. 2013. Pengaruh Penambahan Probiotik Selulolitik (Cellulomonas sp) dalam pakan Terhadap Kualitas Karkas, Lemak Abdominal dan Berat Organ dalam Ayam Pedaging. Jurusan Nutrisi dan Makanan Ternak. Fakultas Peternakan. Universitas Brawijaya. Malang.

USDA. 1977. Poultry Grading Manual. U.S. Government Publising Office. Washington DC.

Wahyu. 1997. Ilmu Nutrisi Unggas. Cetakan ke-4. Gajahmada University Press. Yogyakarta.

Zulkifli., I.J. Ginsos., P.K. Liew and J. Gilbert. 2003. Growth performance and Newcastle disease antibody titres of broiler chickens fed palm-based diets and their response to heat stress during fasting. Arch. Geflugelk. 67:125 -130. 